\title{
EZH2 Inhibitor
}

National Cancer Institute

\section{Source}

National Cancer Institute. EZH2 Inhibitor. NCI Thesaurus. Code C156804.

Any agent that inhibits the histone lysine methyltransferase EZH2. 